Roche, Pharma, JanssenCilag, Novartis, Abbvie, Consultant of: JanssenCilag, Patrizia Sternad: None declared., Florian Popp: None declared., Peter Bartz-Bazzanella: None declared., Cay-Benedict von der Decken: None declared., Kirsten Karberg Speakers bureau: Roche, Sanofi, Abbvie, Lilly, Georg Gauler Speakers bureau: Abbvie, Gilead, Novartis, Lilly, Consultant of: Lilly, Gilead, Abbvie, Patrick Wurth Speakers bureau: Abbvie, Lilly, UCB, Medac, Susanna Spaethling-Mestekemper Speakers bureau: Abbvie, BMS, Celgene, Gilead, GSK, Hexal, Lilly, MSD, Novartis, Pfizer, Sanofi, UCB, Christoph Kuhn: None declared., Matthias Englbrecht Speakers bureau: AbbVie, Chugai, Eli Lilly, Novartis, Roche, Sanofi, Mundipharma, Paid instructor for: AbbVie, Chugai, Roche, Consultant of: AbbVie, Novartis, Roche, Sanofi, Grant/research support from: Roche, Chugai, Wolfgang Vorbrüggen: None declared., Georg Adler: None declared., Martin Welcker Speakers bureau: Abbvie, Actelion, Amgen, Biogen,BMS, Berlin Chemie, Celgene, Galapagos, Gilead, GSK, Hexal, Janssen, Medac, MSD, Mundipharma, Mylan, Novartis, Pfizer, Roche, Sanofi, SOBI, UCB, Grant/research support from: Novartis, Abbvie.

DOI: 10.1136/annrheumdis-2021-eular.1353

\section{AB0495 \\ BIOMECHANICAL STRESS IN THE CONTEXT OF COMPETITIVE SPORTS TRAINING TRIGGERS ENTHESITIS}

D. Simon ${ }^{1}$, A. Kleyer ${ }^{1}$, S. Bayat ${ }^{1}$, J. Knitza ${ }^{1}$, L. Valor ${ }^{1}$, M. Schweiger ${ }^{1}$, G. Schett ${ }^{1}$, K. Tascilar ${ }^{1}$, A. Hueber ${ }^{2} .{ }^{1}$ Friedrich-Alexander University (FAU) Erlangen-Nürnberg and Universitätsklinikum Erlangen, Department of Internal Medicine 3 - Rheumatology and Immunology, Erlangen, Germany; ${ }^{2}$ Sozialstiftung Bamberg, Section Rheumatology, Erlangen, Germany

Background: Preclinical models have indicated that biomechanical stress can trigger entheseal inflammation (1). Furthermore, enthesitis is a hallmark of psoriatic arthritis (PsA) and spondyloarthritis ( $\mathrm{SpA}$ ), suggesting that mechanoinflammation is an important step in their pathogenesis (2). However, the relation between mechanical stress and enthesitis in humans is poorly investigated. Competitive badminton is a demanding stop-and-go sport that strains entheseal sites in particular and provides an opportunity to assess the impact of physical activity on the development of an instant inflammatory response in the entheses.

Objectives: To evaluate the influence of mechanical stress on the development of immediate enthesitis.

Methods: BEAT (Badminton Enthesitis Arthrosonography Study) is an interventional study that assessed entheses in competitive badminton players before and immediately after a 60 -minute intensive training session by ultrasound. Power Doppler (PD) signal and Gray-Scale (GS) changes were evaluated the insertions sites of both Achilles tendon, patellar tendons and lateral humeral epicondyles and quantified using a validated scoring system (3). Pre- and post-training scores were compared using linear mixed-effects models. We used interaction terms to assess possible differential effects on patellar, elbow and Achilles entheses.

Results: Thirty-two badminton players (22 men, 10 women) with an average age of $31.1 \pm 13.0$ years were included (Table 1 ). On average, they had been playing badminton for $16.2 \pm 10.1$ years. 192 entheseal sites were examined twice. The respective empirical total scores for PD examination were $0.1(0.3)$ before and $0.5(0.9)$ after training (Figure 1). Mean total GS scores were 2.9 (2.5) and 3.1 (2.5) before and after training, respectively. The mean total PD score difference of 0.4 between pre- and post -training was significant with a $p$ value of 0.0014 , whereas the $p$ value for the mean total GS score difference of 0.2 was 0.63 . Overall, seven participants $(22 \%)$ showed an increased empirical total PD score. A mixed-effects model showed a significant increase of PD scores after training, with a mean increase per site of $0.06(95 \% \mathrm{Cl} 0.01$ to $0.12, p=0.017)$.

Table 1. Baseline characteristics

\section{Demographic characteristics}

$\mathrm{N}$, total

Females, $\mathrm{N}(\%)$

Age, years (mean $\pm S D)$

Height, cm (mean value \pm SD)

Body weight, $\mathrm{kg}$ (mean value $\pm \mathrm{SD}$ )

Smoking, N (\%)

Alcohol, N (\%)

Concomitant Diseases

Inflammatory bowel disease, N (\%)

Psoriasis, $\mathrm{N}(\%)$

Uveitis, N (\%)

Diabetes mellitus, $\mathrm{N}(\%)$

Hypertension, N (\%)

Sports history

Years Badminton (mean \pm SD)
10 (31.3)

$36.1 \pm 13.0$

$178.6 \pm 9.9$

$74.7 \pm 13.5$

$11(34.4)$

24 (75.0)

0

0

0

$2(6.3)$

$16.2 \pm 10.1$

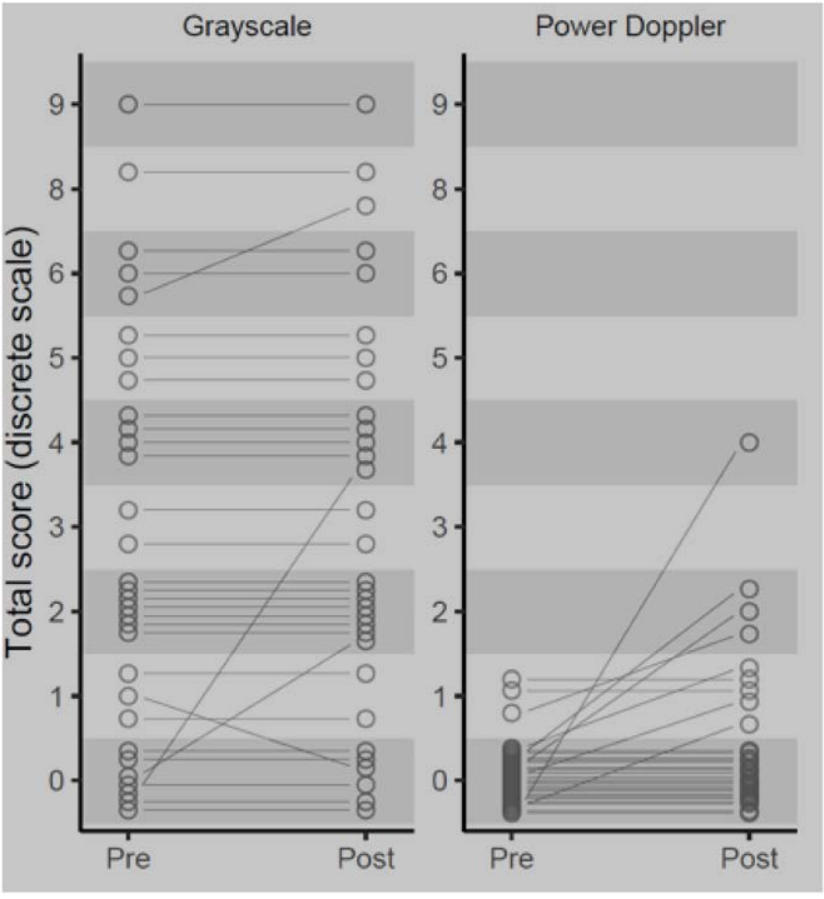

Figure 1. Ultrasound scores before and after trainingFigure 1. A Spaghetti plots depicting inividual Gray-Scale and Power Doppler ultrasound scores before and after training

Conclusion: Mechanical stress leads to rapid inflammatory responses in the entheseal structures of humans. These data support the concept of mechanoinflammation in diseases associated with enthesitis. However, while such responses may be self-contained in healthy subjects, they may be prolonged and more pronounced in certain risk groups, such as patients with PsA or SpA.

\section{REFERENCES:}

[1] Cambré I, et al. Mechanical strain determines the site-specific localization of inflammation and tissue damage in arthritis. Nature Communications. 2018; 9:4613.

[2] Schett G, et al. Enthesitis: from pathophysiology to treatment. Nat Rev Rheumatol. 2017; 13:731-741.

[3] Balint PV, et al. Reliability of a consensus-based ultrasound definition and scoring for enthesitis in spondyloarthritis and psoriatic arthritis: an OMERACT US initiative. Annals of the Rheumatic Diseases. 2018; 77:1730

Disclosure of Interests: David Simon: None declared., Arnd Kleyer: None declared., Sara Bayat: None declared., Johannes Knitza: None declared., Larissa Valor: None declared., Marina Schweiger: None declared., Georg Schett: None declared., Koray Tascilar: None declared., Axel Hueber Grant/research support from: Novartis Research Grant.

DOI: 10.1136/annrheumdis-2021-eular.1793

\section{AB0496 COMPARISON OF THE DISTRIBUTION BY DEPARTMENT OF THE PREVALENCE OF SPONDYLOARTHRITIS AND INFLAMMATORY BOWEL DISEASES IN METROPOLITAN FRANCE AND THEIR EVOLUTION BETWEEN 2008 AND 2018}

O. Fakih ${ }^{1}$, C. Prati ${ }^{1,2}$, D. Wendling ${ }^{1,3}$, F. Verhoeven ${ }^{1,2} .{ }^{1}$ Centre hospitalier régional universitaire de Besançon, Rhumatologie, Besançon, France; ${ }^{2}$ UFR Santé, Université de Franche-Comté, EA 4267 'PEPITE', Besançon, France; ${ }^{3}$ UFR Santé, Université de Franche-Comté, EA 4266 'EPILAB', Besançon, France

Background: Epidemiology of spondyloarthritis $(\mathrm{SpA})$ has been rarely described in France. One study based on a phone survey found a prevalence of $0.30 \%$ in 2001 [1], and another study based on a national cohort showed an estimated prevalence of $0.43 \%$ in 2010 [2]. To our knowledge, there is no data regarding the geographical distribution of SpA in France. Furthermore it is known that SpA occurs in up to $13 \%$ of patients with inflammatory bowel disease (IBD), and that there is a significant north-south gradient in IBD cases in France.

Objectives: To determine the prevalence of SpA and IBD in metropolitan France and compare the geographical distribution of SpA and IBD in 2008 and 2018. 